The Quarterly Journal of Austrian Economics

Volume 23 | NO. 3-4 | 542-567 | FALL/Winter 2020 WWW.QJAE.ORG

\title{
A Subjectivist Approach to TEAM ENTREPRENEURSHIP
}

\author{
Daniel Leunbach, Truls Erikson, and Ekaterina S. Bjornali*
}

JEL Classification: B53, D80, L26

Aвstract: Many scholars have pointed to Austrian subjectivism as an appropriate framework for understanding and studying entrepreneurship. Yet very few empirical studies in the field of entrepreneurship have applied a subjectivist lens. This research article responds to calls for more subjectivist entrepreneurship research by theoretically refining and empirically extending the subjectivist approach to team entrepreneurship. The findings presented in this study, which are based on data from 124 high-tech start-ups founded in Norway, suggest that positive internal and external team dynamics contribute to team effectiveness, as measured by the lead entrepreneur's subjective assessment of his or her team. Implications for theory and practice are discussed.

\section{INTRODUCTION}

ne of the defining characteristics of the Austrian school is its
commitment to subjectivism (Boettke, Lavoie, and Storr 2004;

\footnotetext{
*Daniel Leunbach (daniel.leunbach@sfe.uio.no) is a lecturer at the University of Oslo. Truls Erikson (trulser@ifi.ulo.no) is a professor at the University of Oslo. Ekaterina S. Bjornali (ekaterina.bjornali@ntnu.no) is an associate professor at the Norwegian University of Science and Technology.

The authors would like to thank Professor Bylund and the two anonymous reviewers for their helpful comments. 
Horwitz 1994; Lavoie 1991; Storr 2010). ${ }^{1}$ This is not to say that mainstream economics completely ignores that individuals hold different preferences, beliefs, and expectations, only that Austrians are far more consistent and thoroughgoing in their application of subjectivism (Foss, Klein, and McCaffrey 2019). Within the Austrian tradition, for example, "it is not merely the ends toward which actions are directed that are subjectively determined, but the means as well" (Dempster 1999, 76; see also Garello 1996).

Whereas subjectivism is a defining aspect of Austrian thought, most entrepreneurship scholars, by contrast, tend to adopt an "objectivist" or "functionalist" metatheoretic approach (Jennings, Perren, and Carter 2005; Grant and Perren 2002; Packard 2017). Stated differently, the predominant approach to understanding and explaining entrepreneurial action and outcomes in the field of entrepreneurship is one characterized by a realist ontology, a positivist epistemology, a deterministic view of human agents, and a nomothetic methodology (Grant and Perren 2002; Burrell and Morgan 1979). ${ }^{2}$

The tendency of Austrian economists and entrepreneurship scholars to adopt divergent starting assumptions may discourage or hamper intellectual exchange between these two knowledge domains (MacLeod 2018). Of particular importance to our explanations of social reality is how much agency we are willing to afford the human subject (see Bevir and Blakely 2018; Hacker 2001). If, for instance, we adopt a mechanistic / deterministic image of the human actor as "nothing more than some sort of piano key or organ stop;... so that everything he does is not at all done by his will but by itself,

\footnotetext{
${ }^{1}$ The term subjectivism is difficult to pin down, as it is used differently in different contexts. In the context of Austrian economics, subjectivism refers to the explicit recognition "that the actions of individuals are to be understood only by reference to the knowledge, beliefs, perception and expectations of these individuals" (Kirzner 2002, 64). More broadly, subjectivism refers to "the pre-supposition that the contents of the human mind, and hence decision making, are not rigidly determined by external events." (O'Driscoll and Rizzo 2014, 68).

${ }^{2}$ Notable exceptions include effectuation theory (Sarasvathy 2001) and the theory of entrepreneurial bricolage (Baker and Nelson 2005). Effectuation theory is partly grounded in American pragmatism (Steyaert 2007) and entrepreneurial bricolage draws on social constructivism, and more specifically on Penrose's (1959) subjectivist distinction between the resources in a firm's environment and the firm-specific services derived from those resources (Fischer 2012).
} 
according to the laws of nature" (Dostoevsky 1864, qtd. in Frank 2010, 423), then this will undoubtedly shape our language and our explanations of economic life (Boettke, Coyne, and Leeson 2003). Likewise, if we adopt an image of the human actor as a self-determining and autonomous being, in absolute command of his or her beliefs and actions, then our explanations and our language will look accordingly different. Scholars who adopt polar opposite assumptions about human agency may therefore find themselves divided by "a gulf of mutual incomprehension" (Snow 1959, 4).

Philosophical differences notwithstanding, this article is written in the belief that mutual learning between the Austrian school of economics and the field of entrepreneurship is both possible and desirable. In fact, there is already a vibrant ongoing dialogue between these two areas of knowledge (Berglund 2009; Chiles, Vultee, et al. 2010; Chiles, Tuggle, et al. 2010; Foss, Klein, and McCaffrey 2019; Foss and Klein 2012; Foss et al. 2008; Kor, Mahoney, and Michael 2007; Korsgaard, Berglund, et al. 2016; Mahoney and Michael 2005). Moreover, many recent contributions have pointed specifically to subjectivism (or interpretivism) as a useful alternative framework for understanding and studying entrepreneurship (e.g., Chiles, Tuggle, et al. 2010; Chiles, Vultee, et al. 2010; Foss et al. 2008; Gilbert-Saad, Siedlok, and McNaughton 2018; Leitch, Hill, and Harrison 2010; Jennings, Perren and Carter. 2005; Kor, Mahoney, and Michael 2007; Mahoney and Michael 2005; Packard 2017; Pittaway 2005). Despite these praiseworthy efforts to articulate the potential relevance and value of subjectivism for the field of entrepreneurship, there are still very few examples of empirical studies in the field built on explicit subjectivist foundations (see Chiles, Vultee, et al. 2010). This is both surprising and unfortunate given the subjectivist emphasis on creative agency and imagination - human elements that seem central to any comprehensive understanding of entrepreneurship (Chiles, Vultee, et al. 2010; Gilbert-Saad, Siedlok, and McNaughton 2018; Kier and McMullen 2018; Kor, Mahoney, and Michael 2007; Packard 2017).

This paper responds to calls for more subjectivist entrepreneurship research (see, e.g., Jennings et al. 2005) by empirically extending the subjectivist approach to team entrepreneurship (henceforth, SATE; Bjornali et al. 2017; Foss et al. 2008; Leunbach, Erikson, and Rapp-Ricciardi 2019; Kor, Mahoney, and Michael 2007; Mahoney and Michael 2005; Penrose 1959). Briefly put, SATE is a distinctive approach to 
studying and understanding entrepreneurial teams-first outlined by Nicolai J. Foss, Peter G. Klein, Yasemin Y. Kor, and Joseph T. Mahoney (2008) - that brings together methodological insights and assumptions from Austrian economics, Edith Penrose's (1959) subjectivist resources approach, and the modern resource-based view. It will be useful, for the sake of clarity, to provide some additional theoretical context before developing this study's hypotheses. The next section therefore offers a condensed overview of SATE and briefly explains how SATE differs from the standard objectivist approach that tends to dominate the study of entrepreneurial teams. ${ }^{3}$

\section{The Subjectivist Approach to Team Entrepreneurship}

Unlike classical accounts of entrepreneurship, which tend to portray entrepreneurship as a solitary undertaking (e.g., Cantillion [1755] 1931; Kirzner 1973 Knight 1921; Say 1814), SATE embraces the team as the key unit of analysis. At first glance, it may seem incoherent that an approach that purports to be subjectivist would embrace the team as a focal object of inquiry. As Foss et al. (2008) carefully explain, however, SATE is consistent with subjectivism in that it is cognizant of individual heterogeneity and takes as its starting point that entrepreneurial teams are comprised of individuals with different experiences, interests, interpretations, personality traits, skills, knowledge, expectations, and so on. Moreover, SATE is also consistent with methodological individualism in that it recognizes that we cannot meaningfully ascribe psychological predicates, such as beliefs and intentions, to the team itself, as if it were a kind of agent in its own right (Quinton 1975). In other words, SATE is consistent with the view that "[o]nly individuals have ends and can act to attain them" (Rothbard [1962, 1970] 2009, 2). Yet it is also the case, almost by definition, that there must be more homogeneity in purposes and intentions among the members of an entrepreneurial team than there is between members of different entrepreneurial teams (Elster 1989, 248-49). As King, Felin, and Wetten $(2010,297)$ explain:

\footnotetext{
${ }^{3}$ In this article, the terms entrepreneurial team and new venture team (these are used interchangeably in the literature) are defined as "the group of individuals that is chiefly responsible for the strategic decision making and ongoing operations of a new venture" (Klotz, et al. 2014, 227).
} 
Pursuing "all" heterogeneous goals or preferences simply is not feasible for an organization not only because of costs and identity violations but also because of the limits of organizational attention (Ocasio 1997). In this sense "organization by firm is variety reducing." (Kogut 2000, 408, emphasis added)

Thus, a primary assumption of SATE is that entrepreneurial team members join forces for a strategic purpose and that their association is predicated on the achievement of that shared purpose (Penrose 1959).

Of course, the adoption of a "team perspective" on entrepreneurship is not unique to SATE in itself. In recent years, entrepreneurship researchers have become increasingly interested in entrepreneurial teams (Klotz et al. 2014). As Anna Brattström, Frédéric Delmar, Alan R. Johnson and Karl Wennberg (2020) and many others have explained, however, entrepreneurial team researchers have predominately focused on examining the relationships between team characteristics (e.g., size, demographic diversity) and various types of outcomes while often downplaying or ignoring how team members work together to achieve meaningful outcomes (see also Bjornali et al. 2017; Lechler 2001; Leunbach et al. 2019). SATE, by contrast, focuses explicitly on the ways in which team members with heterogeneous mental models act and interact in subjective and intersubjective processes of "discovery, creativity and learning" (Bjornali et al. 2017, 319) to achieve their shared purposes (Gilbert-Saad, Siedlok, and McNaughton 2018; Packard 2017).

Finally, SATE also differs from standard approaches to studying entrepreneurial teams in that it takes seriously the proposition from Austrian economics "that the future is not merely unknown, but unknowable" (Kor, Mahoney, and Michael 2007, 1188). This proposition follows quite naturally from Austrian assumptions about individual agency, imagination, and choice (see Beckert 2016; Bronk 2009, 215-16; Buchanan and Vanberg 1991; Shackle 1979). ${ }^{4}$ As Gerald P. O’Driscoll Jr. and Mario Rizzo (2014, 69, emphasis in original) point out:

\footnotetext{
${ }^{4}$ As Robert Jackson $(2000,72)$ has put it in another context: "Human behaviour cannot be predicted scientifically because humans have minds, and because they can make up their minds and change their minds concerning the basic question of how they wish to live. They can be quite unpredictable in doing that. They have fertile imaginations."
} 
A world in which there is autonomous or creative decision-making is one in which the future is not merely unknown, but unknowable. There is nothing in the present state of the world that enables us to predict the future state because the latter is underdetermined by the former.... Subjectivism and action under uncertainty are thus inseparable ideas.

By taking uncertainty seriously, SATE allows us to ask different questions, questions that are not being sufficiently addressed in the entrepreneurial team literature. For instance, if the modern capitalist economy is characterized by persistent "novelty, surprise, and instability" (Chiles, Vultee, et al. 2010, 138), and thus exhibits Knightian uncertainty (as opposed to measurable risk), then how can entrepreneurial teams overcome paralysis and make the decision to act, how can they form shared expectations, and how can they convince, communicate, and collaborate with external actors who may be needed in the commercialization effort (see also Beckert 2016; Beckert and Bronk 2018; Bronk 2009; Tuckett 2018)?

Although we still lack satisfactory answers to these questions, any subjectivist answer to them is likely to include some reference to our human capacity for imagination. As Jens Beckert and Richard Bronk $(2018$, 3) have put it, "imagination is not only the root cause of uncertain futures; it is also one of our principal tools for coping with them." In Foss et al.'s (2008) subjectivist framework, for example, the creative imagination also takes center stage. Specifically, Foss et al. (2008, 88, emphasis original) portray entrepreneurship "as a creative team act, where heterogeneous managerial mental models interact in a process that produces a collective output, which is creatively superior to individual entrepreneurship."

Although Foss et al.'s (2008) original formulation of SATE is theoretically rich and built on sound Austrian foundations, it arguably lacks the specificity needed for empirical research. Moreover, Foss et al.'s (2008) framework focuses almost exclusively on the social and cognitive interactions within the entrepreneurial team, thereby discounting the interface between the focal entrepreneurial team and other important constituents whose contributions may also be critical to the successful development of the venture (e.g., investors, pilot customers, alliance partners, suppliers, external advisors, government agencies; see Elert and Henrekson 2019; Garnsey and Heffernan 2005). 
This article attempts to overcome these limitations by developing and testing a conceptual model that includes two key constructs, positive internal dynamics (Foss et al. 2008) and positive external dynamics, to explain team effectiveness. After developing and presenting said model, the research design is described and the findings, based on self-reported data from 124 high-tech start-ups founded in Norway, are presented. The article concludes with a discussion of the theoretical and practical implications.

\section{HYPOTHESES DEVELOPMENT}

\section{Positive External Dynamics and Entrepreneurial Team Effectiveness}

For innovation-based start-ups, a basic challenge is how to successfully communicate and collaborate with external actors whose complementary capabilities and resources are required in order for the venture to survive and grow (Clough et al. 2019; Elert and Henrekson 2019; Gans and Stern 2003; Villanueva, Van de Ven, and Sapienza, 2012). Examples of externally held resources that entrepreneurs need to attract to build their ventures include financial resources (e.g., venture capital financing or bank loans), human capital (e.g., skills from employees, advisors, board members, and business partners), and social capital (e.g., information from customers, suppliers, or other social contacts; see Clough et al. 2019 for an excellent review of the research on entrepreneurial resource mobilization).

Resource mobilization becomes particularly challenging in an Austrian world of dispersed knowledge and heterogeneous expectations (Dew, Velamuri, and Venkataraman 2004; Zander 2007). That is, subjectively held knowledge and heterogeneous expectations imply that it can be prohibitively difficult or costly for entrepreneurs to articulate and communicate their ideas and plans in such a way that relevant others will be able to understand, assess, and accept them (Zander 2007). If the venture is based on complex and highly specialized knowledge, as is often the case with science-based ventures, the likelihood of communication difficulties increases (Miozzo and DiVito 2018). In such a context, an entrepreneurial team's deep knowledge of a particular technological domain may paradoxically limit the team's ability to communicate effectively with 
potential resource providers, a phenomenon known as "the curse of knowledge" (Froyd and Layne 2008; Leunbach et al. 2019). Indeed, the history of science is replete with examples that illustrate just how excruciatingly difficult it can be to champion new ideas based on specialized knowledge of "the particular circumstances of time and place" (Hayek 1945, 521), even when the ideas have clear advantages over existing alternatives (see, e.g., Rogers 2003; Weintraub 2010). The reasons for such communication difficulties include not only nonoverlapping mental models between an idea's champions and potential supporters (Foss and Grandori 2020), but also cognitive biases against novelty (Mueller, Melwani, and Goncalo 2012). To gain acceptance for their ideas, entrepreneurs and innovators may have to frame and present their novel ideas with reference to existing and familiar activities. For example, Kathleen Eisenhardt (2003, ix), describes how managers and engineers at Amazon.com used familiar metaphors such as "shopping cart" and "checkout" to disguise their novel internet technology and overcome resistance.

Of course, many entrepreneurial teams try to circumvent aspects of the resource mobilization process by making creative use of the resources at hand (Baker and Nelson 2005; Penrose 1959) or by using their own personal funds to purchase the inputs they need to exploit an entrepreneurial opportunity (Shane 2003, 167-71). However, most entrepreneurial teams sooner or later have to confront the problem of mobilizing external stakeholder support if they want to realize their plans, even those teams that self-finance and engage in entrepreneurial bricolage (Zott and Huy 2007; Elert and Henrekson 2019).

Research suggests that resource mobilization is an inherently social process, involving communication activities such as persuasion, explanation, sharing of stories, interpretations, and so on (Martens, Jennings, and Jennings 2007; Zott and Huy 2007). In particular, to communicate effectively with a potential stakeholder, an entrepreneurial team must have a reasonably accurate understanding of what the potential stakeholder knows (Nickerson 1999).

The above considerations highlight the central importance of empathic accuracy for mobilizing stakeholders in support of a venture. Empathic accuracy can be defined as the "the ability to accurately infer the specific content of another person's thought and feelings" (Ickes 1993, 588). Some people display a remarkable 
talent for understanding the states of others. It has been said of the philosopher and historian of ideas Isaiah Berlin, for example, that he had "the gift of self-identification with the outlook of holders of widely different, sometimes incompatible points of view-to a degree unique among philosophers." (Magee 2009, 43). Similarly, the bestselling novelist James Patterson attributes his own success to a "golden gut-an ability to sense what's going to appeal to a lot of people" (qtd. in Belsky 2010, 28).

Although people differ in their basic skills of empathy and social understanding (Mar, Oatley, and Peterson 2009), it is reasonable to assume that most entrepreneurs can make a deliberate effort to successfully place themselves in the shoes of potential stakeholders ${ }^{5}$ and that such social imaginative efforts can translate into distinct advantages, including, for example, improved communication with relevant parties outside the focal team and improved venture ideation (Kier and McMullen 2018; McMullen 2015; Nickerson 1999). For example, an entrepreneurial team that strives to inform itself of a potential financier's values, goals, and strategies before delivering a pitch will be more likely to secure financing for their project (all else being equal), than an entrepreneurial team that conducts no such research. Similarly, an entrepreneurial team that goes to great lengths to learn about the values, goals, and everyday concerns of potential customers will be more likely to detect relevant market problems than an entrepreneurial team which places less emphasis on such perspective-taking efforts-an informational advantage that should translate into improved venture ideation (Kier and McMullen 2018; McMullen 2010). The success of the Norwegian web series Skam, for example, has been attributed to a four-month preproduction period during which the series's creators conducted about "50 in-depth 3-hour interviews and 200 school class 'speed interviews' with Norwegian 16-year-old girls and boys" to learn about their everyday concerns and dreams (Redvall 2018, 151).

To summarize, entrepreneurial teams that comprise members who value and engage in positive external dynamics will be more effective than entrepreneurial teams composed of members who

\footnotetext{
${ }^{5}$ Entrepreneurs who fall on the autistic spectrum are a possible exception (see Currie and Ravenscroft 2002).
} 
place less emphasis on engaging in positive external dynamics. Positive external dynamics are social and cognitive interactions between an entrepreneurial team and actors outside of the team (e.g., funders, suppliers, and customers) involving: 1) perspective taking, which helps ensure effective communication between the parties, and 2) a balancing of self- and other interest, which helps facilitate intersubjective agreement between the entrepreneurial team and external actors (McMullen 2010; Nickerson 1999; Galinski et al. 2008). Thus, this study's first hypothesis is: positive external dynamics are associated with venture team effectiveness.

\section{Positive Internal Dynamics}

In explaining team effectiveness, positive external dynamics have been highlighted; however, the social interaction within the team is no less important (Lechler 2001). A key ingredient in Foss et al.'s (2008) original formulation of SATE is the "positive team dynamics" which enable team members to continually (re)combine their knowledge-based assets. Positive team dynamics, according to Foss et al. $(2008,84)$, "involves a healthy mix of debating, which stimulates members to think differently and consider new insights, as well as a shared sense of respect, support, and care for members."

Foss et al. (2008) mainly stress the beneficial role that positive team dynamics play in enabling the team to imagine and create "a collective output that is creatively superior to individual output" (Foss et al. 2008, 73). However, teams that display positive internal dynamics are likely to enjoy a host of other advantages as well, including, for example, improved task coordination, fewer information processing failures, and increased action propensity (Leunbach, Erikson, and Rapp-Ricciardi 2019). Indeed, it is difficult to imagine how a shared sense of identity and purpose can be sustained in the team without mutually supportive interactions within it (see, also, Hambrick 2007).

The discussion above can be summarized in the following hypothesis: positive internal team dynamics will moderate the relationship between positive external team dynamics and the effectiveness of the venturing teams. 


\section{RESEARCH METHODS}

\section{Research Design and Data Collection}

This study is based on survey data collected between 2015 and 2018. The sample was collected in Norway from a population of all the high-tech start-ups satisfying the high-tech NACE categories. A criterion for selection was that the businesses had to fit two main NACE categories: "high-tech knowledge-intensive service" or "high-technology." From an initial sample of around nine hundred firms, a total of 761 firms were contacted, and 149 firms completed the survey, generating a response rate of 20 percent. However, there is complete data for only 124 firms. The survey questionnaires targeted the CEOs of these firms.

\section{Measurements}

This study is based on carefully selected validated items from previous team studies. All measures, with the exception of firm age and team size, were collected using a seven-point scale.

\section{Team Effectiveness}

Although scholars have tried to develop overall measures of organizational financial performance for the field of entrepreneurship (Carton and Hofer 2007), there is still no agreement in the literature on what constitutes the best way to measure entrepreneurial team or venture performance (Blatt 2009; Foo 2011). From a subjectivist standpoint, poor team performance can be seen as an outcome that has fallen short of team members' own goals for their collective activities-goals which are themselves highly idiosyncratic to the team and context dependent (see also Tiplic 2016). If we are committed to a subjectivist perspective, as Dempster $(1999,76)$ points out, then "we must realize that that we cannot, with certainty, identify either the goals of economic actors or even the means by which they perceive those goals may be met"(see, also, Garello 1996). Along such subjectivist lines, Penrose (1959) argued that management teams develop subjective images of the firm's resource base and external environment through learning and that these images, in turn, shape 
the distinct "productive opportunity set" of the firm, i.e., "what the firm can see and take advantage of" (Foss 1998, 484).

In keeping with the Penrosian insight that each entrepreneurial team is unique in the productive possibilities that it collectively envisions and seeks to exploit (Bjornali et al. 2017; Foss et al. 2008; Miozzo and DiVito 2018), the dependent variable in this study reflects the lead entrepreneur's subjective judgment of how well his or her team is doing. Specifically, the following six items from Pearce and Sims (2002) were used to measure team effectiveness: my team copes with change very well; my team changes behavior to meet the demands of the situation; my team is highly effective; my team faces new problems effectively; my team works on important problems; my team does very good work.

Respondents were asked to indicate their level of agreement with these statements on a scale ranging from "totally disagree" (1) to "totally agree" (7). The Cronbach's alpha coefficient for this scale was .895 .

\section{Internal Team Dynamics}

One way in which Foss et al.'s (2008) concept of positive team dynamics can be measured is by using the well-established construct of behavioral integration. Behavioral integration, which was originally introduced by Hambrick (1994) as a way of capturing the essence of "teamness" in top management teams, is a metaconstruct comprised of three key elements: the level of collaborative behavior in the team, the quality and frequency of information exchange between team members, and the degree of shared decision-making that takes place in the team (Mendenhall, Butler, and Ehar 2014).

The behavioral integration items used in this study are derived from Mooney, Holahan, and Amason (2007) and read as follows: team members are mutually responsible for decisions; team members have a clear understanding of the issues and needs of each member; team members help each other solve problems; team members share relevant information with each other; team members share resources with each other. The response options ranged from "totally disagree" (1) to "totally agree" (7). The Cronbach's alpha coefficient for this scale was .911. 


\section{External Team Dynamics}

Positive external dynamics were measured with the following six items from Walter, Auer and Ritter(2006): we analyze what we would like and desire to achieve with each partner; we match the use of resources (e.g., personnel, finances) to the individual relationship; we inform ourselves of our partners' goals, potential, and strategies; we judge in advance which possible partners to talk to about building up relationships; we appoint coordinators who are responsible for the relationships with our partners; we discuss regularly with our partners how we can support each other in our success.

The response options ranged from "statement does not apply at all" (1) to "statement applies completely" (7). The Cronbach alpha for this construct was .831. This variable was also mean centered. Further, team size and firm age were controlled for.

\section{RESULTS}

Table 1 shows the descriptive statistics of the main variables in this study. We can see from the table that the average size of the new venture team is 3.50 members (standard deviation of 1.67) and the average firm age is 10.31 years (standard deviation of 3.50). We can also read items' reliability in parentheses. These variables will be elaborated on in subsequent sections. After the two focal variables were mean centered, the collinearity diagnostics showed acceptable scores (e.g., VIFs $<1.57$ ).

Table 1. Descriptive Statistics with Correlations

\begin{tabular}{l|l|l|l|l|l|l} 
Variables in the Model: & Mean & SD & 1. & 2. & 3. & 4. \\
\hline 1. NVT effectiveness & 5.60 & .87 & $(.895)$ & & & \\
\hline 2. Internal team dynamics & 5.87 & .98 & $.629^{* *}$ & $(.911)$ & & \\
\hline 3. External team dynamics & 4.83 & 1.16 & $.492^{* *}$ & $.458^{* *}$ & $(.831)$ & \\
\hline 4. Team size & 3.50 & 1.67 & .117 & .027 & .140 & \\
\hline 5. Firm age & 10.31 & 3.50 & -.166 & -.132 & -.096 & .075 \\
\hline
\end{tabular}

Significance levels: $+p<.1,{ }^{*} p<.05,{ }^{* *} p<.01 . N=124$. Cronbach alphas in parentheses. Seven-point Likert scale. 
The data set was analyzed with PROCESS macro scripts from Hayes (2013). The next table, table 2, shows the findings of the analysis. The initial column shows the control model. Model 1 shows that the overall relationship between external dynamics and the effectiveness of venturing teams is statistically significant $(B=$ $.183 ; p<.01$ ). This means that external dynamics relate positively to the effectiveness of the venturing teams, as judged by the lead entrepreneur, in support of hypothesis 1 .

From table 2, we also see that the moderator variable directly influences the effectiveness of the venturing teams $(.450, p<.001)$. With respect to the interaction hypothesis, we find that internal team dynamics moderate the relationship between external team dynamics and the effectiveness of venturing teams $(B=-.061 ; p<.1)$.

\section{Table 2. Regression Results with Unstandardized Coefficients (Standard Errors in Parentheses)}

\begin{tabular}{|l|l|l|l}
\hline & $\begin{array}{l}\text { Control Model } \\
\text { NVT Effectiveness }\end{array}$ & $\begin{array}{l}\text { Model 1 } \\
\text { NVT Effectiveness }\end{array}$ & $\begin{array}{l}\text { Model 2 } \\
\text { NVT Effectiveness }\end{array}$ \\
\hline (Constant) & $5.811^{* * *}(.282)$ & $5.669^{* * *}(.215)$ & $5.717^{* * *}(.215)$ \\
\hline Firm age & $-.044^{*}(.022)$ & $-.020(.017)$ & $-.020(.017)$ \\
\hline NVT size & $.068(.047)$ & $.039(.036)$ & $.032(.036)$ \\
\hline Internal team dynamics & & $.450^{* * *}(.068)$ & $.392^{* * *}(.075)$ \\
\hline External team dynamics & & $.183^{* *}(.058)$ & $.184^{* *}(.057)$ \\
\hline Internal x External team dynamics & & & $-.061+(.034)$ \\
\hline F-value & $2.813+$ & $25.332^{* * *}$ & $21.286^{* * *}$ \\
\hline Adjusted $\mathrm{R}^{2}$ & .029 & .442 & .452 \\
\hline F-change & $2.813+$ & $45.768^{* * *}$ & $3.217+$ \\
\hline
\end{tabular}

Significance levels: $+p<.10,{ }^{*} p<.05,{ }^{* *} p<.01,{ }^{* * *} p<.001 ; N=124$.

Balancing Type I and Type II errors, the traditional cutoff for interaction is at the .1 level (Aguinis et al. 2011). The interaction term is significant at the .1 level. As such, there is support for hypothesis 2 regarding interaction. That is, not only does the moderator variable directly influence the effectiveness of the venturing teams, but the variable also negatively moderates the relationship between external dynamics and the effectiveness of the venturing teams, which means that higher levels of internal team dynamics reduce the influence 
of external team dynamics. Figure 1 below visually shows how the interaction works. The figure illustrates that higher levels of external team dynamics relate to improved effectiveness and that this is especially true when the internal team dynamics are high.

Figure 1. Visualizing the Interaction between Internal and External Team Dynamics

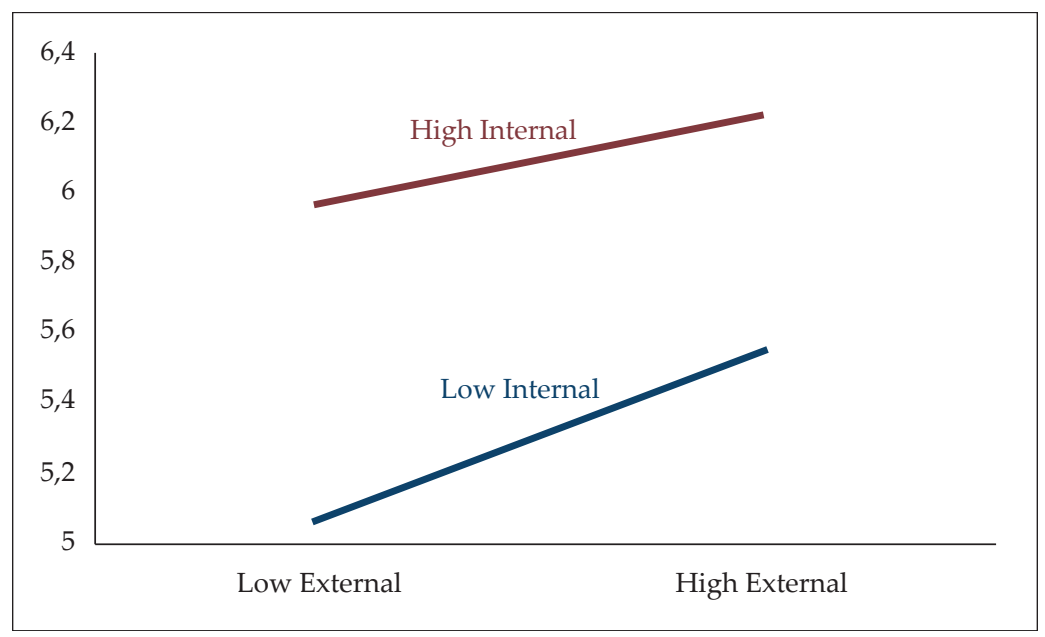

\section{DISCUSSION}

As noted in the introduction, in spite of commendable efforts by many scholars to articulate the potential relevance and value of subjectivism for the field of entrepreneurship, entrepreneurship researchers have generally refrained from adopting subjectivism as a framework for their empirical research. To address this state of affairs, this paper has endeavored to provide a useful example of subjectivism in action which hopefully can inspire other entrepreneurship scholars to consider subjectivism as a metatheoretical foundation for their empirical research.

Although subjectivism may seem of concern only to a small group of scholars interested in the philosophical foundations of entrepreneurship research, it should in fact concern anyone who 
cares about the practical relevance of the field of entrepreneurship. In a recent essay, for example, Dimo Dimov, Reiner Schaefer, and Joseph Pistrui (2020) warn that the field of entrepreneurship is in danger of becoming irrelevant to practicing entrepreneurs unless entrepreneurship scholars take more seriously "entrepreneurs' first-person practical decision-making perspective" (p. 2). Similarly, James C. Hayton and Magdalena Cholakova (2012) argue that we cannot understand the emergence of entrepreneurial opportunities without examining "the microprocesses by which entrepreneurial ideas and intentions are represented and interpreted in the minds of those who develop them." (p. 41). These arguments are in basic accord with subjectivism, and suggest that the field of entrepreneurship can benefit from a much closer dialogue with the Austrian tradition. ${ }^{6}$

In addition to highlighting the potential value of Austrian subjectivism for the field of entrepreneurship, this study presents empirical findings that should be of interest to both entrepreneurial team researchers and Austrian economists. Specifically, by clarifying and highlighting the important role that positive external team dynamics play in promoting team effectiveness, this study not only extends the subjectivist approach to team entrepreneurship as originally formulated by Foss et al. (2008), but it also adds empirical weight to Austrian arguments about the practical need for entrepreneurs to invest in what Hunter Hastings, Fernando D'Andrea, and Per Bylund (2019) call "market-making activities." The concept of market-making activities still lacks a crisp definition, but it includes (for example) information-gathering attempts by entrepreneurs to understand customers' "felt uneasiness" (Hastings, D'Andrea, and Bylund 2019, 7) for the purposes of framing and designing a solution which can help alleviate that uneasiness (see also Godley and Casson 2015).

\footnotetext{
${ }^{6}$ To be clear, while we agree with Dimov et al.'s (2020) basic claim that the field of entrepreneurship can gain in practical relevance by taking more seriously the 'subjective perspectives' of the entrepreneurs that it studies, we do not think that subjectivism is immune from criticism. For example, because subjectivism is an epistemological framework that axiomatically presumes human agency, it leaves itself open to the critique that it underestimates the extent to which situational factors (Ross and Nisbett, 2011) and unconscious processes (Wilson, 2004) drive human choices and behavior.
} 
As with all studies, however, there are also limitations that offer opportunities for further research. For example, the key informants approach used in this study rests on the assumption that there is considerable homogeneity in perceptions and interpretations within the entrepreneurial team. However, other members of the entrepreneurial team could potentially have rated their team differently, which would have led to different results. In the earliest stages of entrepreneurial team formation, for example, there is likely to be considerable heterogeneity of perceptions and interpretations among prospective team members. Although we are beginning to learn more about entrepreneurial team formation processes (for an overview of this literature, see Lazar et al. 2020), we still lack a clear understanding of how team members are able to negotiate and arrive at a shared understanding of their team's overall means-ends framework. Indeed, research has tended to focus primarily on the practical challenge that entrepreneurs face in negotiating intersubjective agreement with external market participants, whose resource contributions may be needed in order for the venture to develop and grow (Clough et al. 2019; see also Dew, Velamuri, and Venkataraman 2004; Zander 2007). However, reaching intersubjective agreement within the initial founding team itself is no less important. To borrow a fitting phrase from Roger Scruton $(2014,33)$, "There has to be a firstperson plural, a 'we,'" if team members are to stay together and remain excited about their ideas (see also, Higgins 2019). Future research could shed light on this important topic by observing entrepreneurial teams closely from their earliest inception. This could be achieved, for example, in an incubator or entrepreneurship education setting.

\section{REFERENCES}

Aguinis, Herman, Dan R. Dalton, Frank A. Bosco, Charles A. Pierce, and Catherine M. Dalton. 2011. "Meta-Analytic Choices and Judgment Calls: Implications for Theory Building and Testing, Obtained Effect Sizes, and Scholarly Impact." Journal of Management 37, no. 1: 5-38.

Baker, Ted, and Reed E. Nelson. 2005. "Creating Something from Nothing: Resource Construction through Entrepreneurial Bricolage." Administrative Science Quarterly 50, no. 3: 329-66. 
Beckert, Jens. 2016. Imagined Futures: Fictional Expectations and Capitalist Dynamics. Cambridge, Mass.: Harvard University Press.

Beckert, Jens, and Richard Bronk, eds. 2018. Uncertain Futures: Imaginaries, Narratives, and Calculation in the Economy. Oxford: Oxford University Press.

Belsky, Scott. 2010. Making Ideas Happen: Overcoming the Obstacles between Vision and Reality. New York: Penguin.

Berglund, Henrik. 2009. "Austrian Economics and the Study of Entrepreneurship: Concepts and Contributions." Paper presented at the Academy of Management Conference, Chicago.

Bevir, Mark, and Jason Blakely. 2018. Interpretive Social Science: An Anti-naturalist Approach. Oxford: Oxford University Press.

Bjornali, Ekaterina S., Mirjam Knockaert, Nicolai J. Foss, Daniel Leunbach, and Truls Erikson. 2017. "Unraveling the Black Box of New Venture Team Processes." Pp. 313-48 in The Wiley Handbook of Entrepreneurship, ed. Gorkan Ahmetoglu, Tomas Chamorro-Premuzic, Bailey Klinger, and Tessa Karcisky. Hoboken, N.J.: John Wiley and Sons.

Boettke, Peter J., Christopher J. Coyne, and Peter T. Leeson. 2003. “Man as Machine: The Plight of 20th Century Economics." Annals of the Society for the History of Economic Thought 43, no. 43: 1-10.

Boettke, Peter J., Don Lavoie, and Virgil Henry Storr. 2004. "The Subjectivist Methodology of Austrian Economics and Dewey's Theory of Inquiry." Pp. 327-56 in Dewey, Pragmatism, and Economic Methodology, ed. Elias L. Khalil. London: Routledge.

Brattström, Anna., Frédéric Delmar, Alan R. Johnson and Karl Wennberg. 2020 . "A longitudinal project of new venture teamwork and outcomes."Pp 309-334 in Research Handbook on Entrepreneurial Behavior, Practice and Process, ed. William B. Gartner and Bruce T. Teague. Edward Elgar Publishing.

Bronk, Richard. 2009. The Romantic Economist: Imagination in Economics. Cambridge: Cambridge University Press.

Buchanan, James M., and Viktor J. Vanberg. 1991. “The Market as a Creative Process." Economics and Philosophy 7, no. 2: 167-86.

Burrell, Gibson, and Gareth Morgan. 1979. Sociological Paradigms and Organizational Analysis. London: Heinemann. 
Cantillon, Richard. [1755] 1931. Essai sur la nature du commerce en général. Ed. and trans. Henry Higgs. London: Macmillan.

Chiles, Todd H., Christopher S. Tuggle, Jeffery S. McMullen, Leonard Bierman, and Daniel W. Greening. 2010. "Dynamic Creation: Extending the Radical Austrian Approach to Entrepreneurship." Organization Studies 31, no. 1: 7-46.

Chiles, Todd H., Denise M. Vultee, Vishal K. Gupta, Daniel W. Greening, and Christopher S. Tuggle. 2010. "The Philosophical Foundations of a Radical Austrian Approach to Entrepreneurship." Journal of Management Inquiry 19, no. 2: 138-64.

Clough, David R., Tommy Pan Fang, Balagopal Vissa, and Andy Wu. 2019. "Turning Lead into Gold: How Do Entrepreneurs Mobilize Resources to Exploit Opportunities?" Academy of Management Annals 13, no. 1: 240-71.

Currie, Gregory, and Ian Ravenscroft. 2002. Recreative Minds: Imagination in Philosophy and Psychology. Oxford: Clarendon Press of Oxford University Press.

Dempster, Gregory M. 1999. "Austrians and Post Keynesians: The Questions of Ignorance and Uncertainty." Quarterly Journal of Austrian Economics 2, no. 4: 73-81.

Dew, Nicholas, S. Ramakrishna Velamuri, and Sankaran Venkataraman. 2004. "Dispersed Knowledge and an Entrepreneurial Theory of the Firm." Journal of Business Venturing 19, no. 5: 659-79.

Dimov, Dimo, Reiner Schaefer, and Joseph Pistrui. 2020. "Look Who Is Talking... and Who Is Listening: Finding an Integrative "We" Voice in Entrepreneurial Scholarship." Entrepreneurship Theory and Practice. https://doi.org/10.1177\%2F1042258720914507.

Eisenhardt, Kathleen. 2003. Foreword to How Breakthroughs Happen: The Surprising Truth about How Companies Innovate, Pp. vii-x, by Andrew Hargadon. Cambridge, Mass.: Harvard Business School Press.

Elert, Niklas, and Magnus Henrekson. 2019. "The Collaborative Innovation Bloc: A New Mission for Austrian Economics." Review of Austrian Economics 32, no. 4: 295-320.

Elster, Jon. 1989. The Cement of Society: A Survey of Social Order. Cambridge: Cambridge University Press. 
Foss, Nicolai J. 1998. "The Competence-Based Approach: Veblenian Ideas in the Modern Theory of the Firm." Cambridge Journal of Economics 22, no. 4: 479-95.

Foss, Nicolai J., and Anna Grandori. 2020. “Entrepreneurship and the Firm: A Conversation on Foundations and Prospects." Industrial and Corporate Change 29, no. 3: 581-98.

Foss, Nicolai J., and Peter G. Klein. 2012. Organizing Entrepreneurial Judgment: A New Approach to the Firm. Cambridge: Cambridge University Press.

Foss, Nicolai J., Peter G. Klein, Yasemin Y. Kor, and Joseph T. Mahoney. 2008. "Entrepreneurship, Subjectivism, and the Resource-Based View: Toward a New Synthesis." Strategic Entrepreneurship Journal 2, no. 1: 73-94.

Foss, Nicolai J., Peter G. Klein, and Matthew McCaffrey. 2019. Austrian Perspectives on Entrepreneurship, Strategy, and Organization. Cambridge: Cambridge University Press.

Frank, Joseph. 2010. Dostoevsky: A Writer in His Time. Ed. Mary Petrusewicz. Princeton, N.J.: Princeton University Press.

Froyd, Jeff, and Jean Layne. 2008. "Faculty Ddevelopment Strategies for Overcoming the 'Curse of Knowledge."' Pp. S4D-13-S4D-16 in 2008 38th Annual Frontiers in Education Conference. IEEE. https://doi. org/10.1109/FIE.2008.4720529.

Galinsky, Adam D., William W. Maddux, Debra Gilin, and Judith B. White. 2008. "Why It Pays to Get Inside the Head of Your Opponent: The Differential Effects of Perspective Taking and Empathy in Negotiations." Psychological Science 19, no. 4: 378-84.

Gans, Joshua S., and Scott Stern. 2003. "The Product Market and the Market for 'Ideas': Commercialization Strategies for Technology Entrepreneurs." Research policy 32, no. 2: 333-50.

Garello, Pierre. 1996. "Uncertainty and Subjectivism: The Role of Uncertainty in the Austrian School." In Uncertainty in Economic Thought, ed. Christian Schmidt. Cheltenham, U.K.: Edward Elgar.

Gilbert-Saad, Antoine, Frank Siedlok and Rod B. McNaughton. 2018. "Decision and design heuristics in the context of entrepreneurial uncertainties." Journal of Business Venturing Insights, no. 9: 75-80. 
Godley, Andrew C., and Mark C. Casson. 2015. “'Doctor, Doctor...' Entrepreneurial Diagnosis and Market Making." Journal of Institutional Economics 11, no. 3: 601-21.

Grant, Paul, and Lew Perren. 2002. "Small Business and Entrepreneurial Research: Meta-theories, Paradigms and Prejudices." International Small Business Journal 20, no. 2: 185-211.

Hacker, P. M. S. 2001. "Wittgenstein and the Autonomy of Humanistic Understanding." Pp. 39-74 in Wittgenstein, Theory, and the Arts, ed. Richard Allen and Malcolm Turvey. London: Routledge.

Hambrick, Donald. C. 1994. “Top Management Groups: A Conceptual Integration and Reconsideration of the 'Team' Label." Pp. 171-214 in Research in Organizational Behavior, ed. Barry M. Staw and L. L. Cummings. Vol. 16. Greenwich, Conn.: JAI Press.

—. 2007. “Upper Echelons Theory: An Update.” Academy of Management Review 32, no. 2: 334-43.

Hastings, Hunter., Fernando A. M. C. D'Andrea, and Per Bylund. 2019 “Towards A Value-Dominant Logic of Marketing." MISES: Interdisciplinary Journal of Philosophy, Law and Economics, 7, no 3.

Hayek, F. A. 1945. "The Use of Knowledge in Society." American Economic Review 35: 519-30.

Hayton, James C., and Magdalena Cholakova. 2012. "The Role of Affect in the Creation and Intentional Pursuit of Entrepreneurial Ideas." Entrepreneurship Theory and Practice 36, no. 1: 41-67. https://doi. org/10.1111\%2Fj.1540-6520.2011.00458.x.

Higgins, Edward T. 2019. Shared Reality: What Makes Us Strong and Tears Us Apart. Oxford University Press.

Horwitz, Steven. 1994. "Subjectivism." Pp. 17-22 in The Elgar Companion to Austrian Economics, ed. Peter J. Boettke. Cheltenham, U.K.: Edward Elgar.

Ickes, William. 1993. "Empathic Accuracy." Journal of Personality 61, no. 4: 587-610.

Jackson, Robert H. 2000. The Global Covenant: Human Conduct in a World of States. Oxford: Oxford University Press 
Jennings, Peter L., Lew Perren and Sara Carter. 2005. Guest editors' introduction: Alternative perspectives on entrepreneurship research. Entrepreneurship Theory and Practice, 29, no. 2: 145-152.

Kier, Alexander S., and Jeffery S. McMullen. 2018. "Entrepreneurial Imaginativeness in New Venture Ideation." Academy of Management Journal 61, no. 6: 2265-95.

King, Brayden G., Teppo Felin, and David A. Whetten. 2010. “PerspectiveFinding the Organization in Organizational Theory: A Meta-Theory of the Organization as a Social Actor." Organization Science 21, no. 1: 290-305.

Kirzner Israel M. 1973. Competition and Entrepreneurship. Chicago: University of Chicago Press:

- 2002. The Meaning of the Market Process: Essays in the Development of Modern Austrian Economics. London: Routledge

Klotz, Anthony C., Keith M. Hmieleski, Bret H. Bradley, and Lowell W. Busenitz. 2014. "New Venture Teams: A Review of the Literature and Roadmap for Future Research." Journal of Management 40, no. 1:226-55.

Korsgaard, Steffen, Henrik Berglund, Claus Thrane, and Per Blenker. 2016. "A Tale of Two Kirzners: Time, Uncertainty, and the 'Nature' of Opportunities." Entrepreneurship Theory and Practice 40, no. 4: 867-89.

Knight, Frank H. [1921] 1964. Risk, Uncertainty and Profit. New York: Augustus M. Kelley.

Kor, Yasemin Y., Joseph T. Mahoney, and Steven C. Michael. 2007. "Resources, Capabilities and Entrepreneurial Perceptions." Journal of Management Studies 44, no. 7: 1187-1212.

Lavoie, Don. 1991. “The Progress of Subjectivism." Pp. 470-91 in Appraising Economic Theories: Studies in the Methodology of Research Programs, ed. Neil de Marchi and Mark Blaug. Aldershot, U.K.: Edward Elgar.

Lazar, Moran, Ella Miron-Spektor, Rajsjree Agarwal, Miriam Erez, Brent Goldfarb, and Gilad Chen. 2020. "Entrepreneurial Team Formation." Academy of Management Annals 14, no. 1: 29-59.

Lechler, Thomas. 2001. "Social Interaction: A Determinant of Entrepreneurial Team Venture Success." Small Business Economics 16, no. 4: 263-78. 
Leitch, Claire M., Frances M. Hill, and Richard T. Harrison. 2010. “The Philosophy and Practice of Interpretivist Research in Entrepreneurship: Quality, Validation, and Trust." Organizational Research Methods 13, no. 1: 67-84.

Leunbach, Daniel, Truls Erikson, and Max Rapp-Ricciardi. 2019. “Muddling through Akerlofian and Knightian Uncertainty: The Role of Sociobehavioral Integration, Positive Affective Tone, and Polychronicity." Journal of International Entrepreneurship 18: 1-20.

MacLeod, Miles. 2018. "What Makes Interdisciplinarity Difficult? Some Consequences of Domain Specificity in Interdisciplinary Practice." Synthese 195, no. 2: 697-720.

Magee, Bryan. 2009 "Isaiah as I Knew Him." Pp. 40-54 in The Book of Isaiah: Personal Impressions of Isaiah Berlin, ed. Henry Hardy. Woodbridge, U.K.: Boydell Press.

Mahoney, Joseph T., and Steven C. Michael. 2005. Pp. 33-54 in "A Subjectivist Theory of Entrepreneurship." In Handbook of Entrepreneurship Research: Interdisciplinary Perspectives, ed. Sharon A. Alvarez, Rajshree Agarwal, and Olav Sorenson. Boston: Springer.

Mar, Raymond A., Keith Oatley, and Jordan B. Peterson. 2009. “Exploring the Link between Reading Fiction and Empathy: Ruling out Individual Differences and Examining Outcomes." Communications 34, no. 4: 407-28.

Martens, Martin L., Jennifer E. Jennings, and P. Devereaux Jennings. 2007. "Do the Stories They tell get them the Money They Need? The Role of Entrepreneurial Narratives in Resource Acquisition." Academy of Management Journal 50, no. 5: 1107-32.

Mendenhall, Mark E., Frank Christopher Butler, and Andrew F. Ehat. 2014. "Toward a Refinement of the Meta-Construct of Behavioral Integration in Upper Echelons Theory." Academy of Management Proceedings 2014, no. 1: 11626.

Miozzo, Marcela, and Lori DiVito. 2018. "Productive Opportunities, Uncertainty, and Science-Based Firm Emergence." Small Business Economics 54: 1-22.

McMullen, Jeffery S. 2010. "Perspective Taking and the Heterogeneity of the Entrepreneurial Imagination." Pp. 113-43 in What Is So Austrian about Austrian Economics?, ed. Roger Koppl, Steven Horwitz, and Pierre Desrochers. Vol. 14 of Advances in Austrian Economics. Bingley, U.K.: Emerald Books. 
. 2015. "Entrepreneurial Judgment as Empathic Accuracy: A Sequential Decision-Making Approach to Entrepreneurial Action." Journal of Institutional Economics 11, no. 3: 651-81.

Mueller, Jennifer S., Shimul Melwani, and Jack A. Goncalo. 2012. "The Bias against Creativity: Why People Desire but Reject Creative Ideas." Psychological science 23, no. 1: 13-17.

Mooney, Ann C., Patricia J. Holahan, and Allen C. Amason. 2007. “Don't Take It Personally: Exploring Cognitive Conflict as a Mediator of Affective Conflict." Journal of Management Studies 44, no. 5: 733-58.

Nickerson, R. S. 1999. "How We Know - and Sometimes Misjudge-What Others Know: Imputing One's Own Knowledge to Others." Psychological Bulletin 125, no. 6: 737-59.

O'Driscoll, Gerald P., Jr., and Mario J. Rizzo. 2014. Austrian Economics Re-examined: The Economics of Time and Ignorance. Abingdon, U.K.: Routledge.

Pittaway, Luke. 2005. "Philosophies in Entrepreneurship: A Focus on Economic Theories." International Journal of Entrepreneurial Behavior and Research 11, no. 3: 201-21.

Pearce, C. L., H. P. Sims Jr. 2002. “Vertical versus Shared Leadership as Predictors of the Effectiveness of Change Management Teams: An Examination of Aversive, Directive, Transactional, Transformation, and Empowering Leader Behaviors." Group Dynamics: Theory, Research, and Practice 6, no. 2: 172-97.

Penrose, Edith. [1959] 2009. The Theory of the Growth of the Firm. 4th ed. Oxford: Oxford University Press.

Quinton, Anthony. 1975. "Social Objects." Proceedings of the Aristotelian Society, 76: 1-27).

Redvall, Eva Novrup. 2018. “Reaching Young Audiences through Research: Using the NABC Method to Create the Norwegian Web Teenage Drama SKAM/Shame." Pp. 143-61 in True Event Adaptation: Scripting Real Lives, ed. Davinia Thornley. Cham, Switzerland: Palgrave Macmillan.

Rogers, Everett M. 2003. Diffusion of Innovations, 5th ed. New York, Free Press.

Ross, Lee, and Richard E. Nisbett. 2011. The Person and the Situation: Perspectives of Social Psychology. London: Pinter and Martin. 
Rothbard, Murray N. [1962, 1970] 2009. Man, Economy, and State with Power and Market. 2d scholar's ed. Auburn, Ala.: Ludwig von Mises Institute.

Say, Jean-Baptiste. 1814. Traité d'économie politique, ou simple exposition de la manière dont se forment, se distribuent, et se consomment les richesses. $2 \mathrm{~d}$ ed. Paris: Antoine-Augustin Renouard.

Scruton, Roger. 2014. How to Be a Conservative. London: Bloomsburg.

Shackle, G. L. S. 1979. Imagination and the Nature of Choice. Edinburgh: Edinburgh University Press.

Snow, C. P. 1959. The Two Cultures and the Scientific Revolution. Cambridge: Cambridge University Press

Steyaert, Chris. 2007. “'Entrepreneuring' as a Conceptual Attractor? A Review of Process Theories in 20 Years of Entrepreneurship Studies. Entrepreneurship and Regional Development 19: 453-77.

Storr, Virgil Henry. 2010. "The Facts of Social Sciences Are What People Believe and Think." Pp. 30-41 in Handbook of Austrian Economics, ed. Peter J. Boettke. Cheltenham, U.K.: Edward Elgar Publishing.

Tiplic, Dijana. 2016. "Aspiration Levels and Learning." In The Palgrave Encyclopedia of Strategic Management, ed. Mie Augier and David J. Teece. London: Palgrave Macmillan.

Tuckett, David. 2018. "Conviction Narrative Theory and Understanding Decision-Making in Economics and Finance," in R. Beckert and R. Bronk (eds) Uncertain Futures: Imaginaries, Narratives, and Calculation in the Economy, ed. Jens Beckert and Richard Bronk. Oxford: Oxford University Press.

Villanueva, Jaume, Andrew H. Van de Ven, and Harry J. Sapienza. 2012. "Resource Mobilization in Entrepreneurial Firms." Journal of Business Venturing 27, no. 1: 19-30.

Walter, Achim, Michael Auer and Thomas Ritter. 2006."The impact of network capabilities and entrepreneurial orientation on university spin-off performance." Journal of Business Venturing, 21, no. 3: 541-567.

Weintraub, Pamela. 2010. "The Doctor Who Drank Infectious Broth, Gave Himself an Ulcer, and Solved a Medical Mystery." Discover, Apr. 8, 2010. https://www.discovermagazine.com/health/the-doctor-who-drankinfectious-broth-gave-himself-an-ulcer-and-solved-a-medical-mystery. 
Wilson, Timothy D. 2004. Strangers to Ourselves: Discovering the Adaptive Unconscious. Cambridge, Mass.: Belknap Press of Harvard University Press.

Zander, Ivo. 2007. "Do You See What I Mean? An Entrepreneurship Perspective on the Nature and Boundaries of the Firm." Journal of Management Studies, 44, no. 7: 114-64.

Zott, Christoph, and Quy Nguyen Huy. 2007. "How Entrepreneurs Use Symbolic Management to Acquire Resources." Administrative Science Quarterly 52, no. 1: 70-105. 